Article

\title{
Effect of Religious and Cultural Information of Olive Oil on Consumer Behavior: Evidence from Japan
}

\author{
Tamaki Kitagawa ${ }^{1, *}$, Kenichi Kashiwagi ${ }^{2}$ and Hiroko Isoda ${ }^{3}$ \\ 1 Alliance for Research on the Mediterranean and North Africa, University of Tsukuba, 1-1-1 Tennodai, \\ Tsukuba, Ibaraki 305-8577, Japan \\ 2 Faculty of Humanities and Social Sciences, Alliance for Research on the Mediterranean and North Africa, \\ University of Tsukuba, 1-1-1 Tennodai, Tsukuba, Ibaraki 305-8577, Japan; \\ kashiwagi.kenichi.fn@u.tsukuba.ac.jp \\ 3 Faculty of Life and Environmental Sciences, Alliance for Research on the Mediterranean and North Africa, \\ University of Tsukuba, 1-1-1 Tennodai, Tsukuba, Ibaraki 305-8577, Japan; isoda.hiroko.ga@u.tsukuba.ac.jp \\ * $\quad$ Correspondence: kitagawa.tamaki.kb@u.tsukuba.ac.jp; Tel.: +81-(0)29-853-3982
}

Received: 18 December 2019; Accepted: 19 January 2020; Published: 22 January 2020

check for updates

\begin{abstract}
The olive tree and oil are iconic in the Mediterranean culture and religions, and producers incorporate those associations into the packaging of olive oil products they distribute regionally. This study examines the impact of religious and cultural information about olive oil on consumer behavior. A choice experiment was conducted to survey Japanese consumers' willingness to pay for olive oil products. Results show that consumers respond with varying degrees of favor to the characteristic of "produced in pilgrimage destination," but if cultural and religious information related to olive is provided, their willingness to pay increases 6.7 times. Measurements of cross-effects show that consumers that are more educated respond favorably to cultural and religious imagery, whereas older consumers and those with more children respond less favorably. Empirical results imply those regional religious and cultural allusions could be used to differentiate and promote olive oil products in a culturally distinct market.
\end{abstract}

Keywords: olive oil; religious and cultural attributes; country of origin; choice experiment; willingness to pay

\section{Introduction}

Olive oil had historically been produced and consumed only in the limited regions across the Mediterranean basin and the Middle East. It is just since the last few decades that olive oil started to be consumed in the global market. According to the International Olive Council, the value of olive oil consumption in the crop year of 2017/2018 (from October 2017 to September 2018) in the historical producing countries where olive oil is mainly exported, increased by $50.9 \%$ compared with the value in 1990/1991, and that of the non-historical producing countries increased by $251.2 \%$. Production has risen with consumption. World production of olive oil rose from 1,453,000 tons in 1991/1992 to $3,314,000$ tons in 2017/2018. Olive orchards spread from the Mediterranean and Mideast to South and North America, Asia, and Oceania. Australia, China, and the USA have increased production significantly [1]. The Chinese government promotes the planting of olive trees, and their number rivals the number of olive trees planted in one of the biggest promoting regions in Spain [2]. As the competition among olive oil producers intensifies, producers in traditional regions are expected to differentiate their products. On the other hand, the elements that can be incorporated into value-added products as characteristics of olives in the Mediterranean world are not limited to health functions and taste. The terroir of olive oil combining local climates, landscapes, and cultures can be one of the attractiveness of the product [3-6]. 
Geographical Indications are now one of the essential factors in the olive oil differentiation strategy. The survey of Dekhili et al. in Tunisia and France investigated that the image of the region of origin of the products affects the overall perception of olive oil by consumers [7]. Panzone et al. confirmed that the insider consumers are willing to pay more for the olive oil from the region they identify with than the outsiders [8]. Tempesta et al. determined that the origin of olive oil was one of the most critical clues considered by consumers, although the impact became less in the region where olive cultivation is not dominant [9]. These studies show that olive oil is now a terroir product and that information about the origin can influence consumer quality perception and behavior. However, little has been said about what constitutes the strong historical and symbolic links between regions and foods other than indirect elements such as landscape.

Since Antiquity, diverse religious traditions have colored the cultural peculiarity of the Mediterranean olive oil. The Mediterranean has affixed great importance to the cultural and religious connotations of olive trees and oil. Greek mythology regards the olive tree on the Acropolis of Athens as sacred, which Athena planted to create the order against the maritime dominance of Poseidon [10], and it was central to rituals during the Panathenaia festival [11]. Roman deities Mars and Pax are depicted holding an olive branch as a symbol of peace and order. Olive trees and oil hold special places in Abrahamic texts and rituals of Confirmation or Hanukah. Olives embody God's grace in Islam (Quran 6:141, 16:11, 24:35, 80:29, 95:1). Indigenous cultures sacralize olives and olive oil in local myths, rituals, and folktales [12-14]. Purification rituals in North Africa involve olive branches or oil, and old olive trees are venerated as saints [15]. However, previous studies have seldom discussed the value of the rich olive-related cultures and religious backgrounds of the Mediterranean world addible to olive oil products, which clearly articulates and characterizes the terroir. At this point, there is a research gap where we try to contribute.

The rich cultural and religious backgrounds, unique to the Mediterranean region, are expected to be useful in differentiating Mediterranean olive oil. Olive oil producers in Greece, Italy, Israel, Palestine, and Tunisia invoke that religious and cultural imagery in their marketing (Figure 1). Product labels proclaim "holy," "sacred," and Barka, the Arabic term for "God's blessing." The designs show symbols of Athena as a guardian goddess of olive production, a figure of David under the olive tree, and images of saints. These products employ the images with a high affinity to olive shared within a particular region or culture. However, it is crucial to measure the impact of religious and cultural values on olive oil consumers worldwide since religions and cultures are considered to affect consumer's buying behavior due to the roles to create social values that people depend on $[16,17]$. It is also because the images of the Mediterranean formed among foreign countries are considered to contribute to the circulation of olive oil under the global expansion of the market [5].

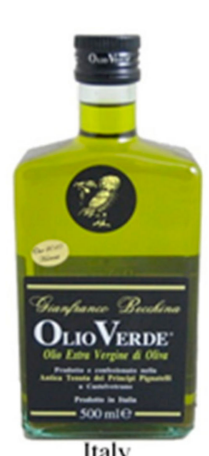

Italy

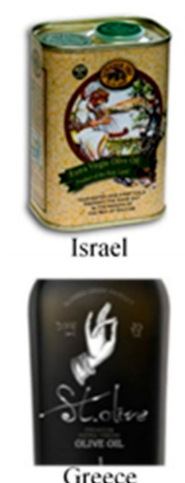

Greece
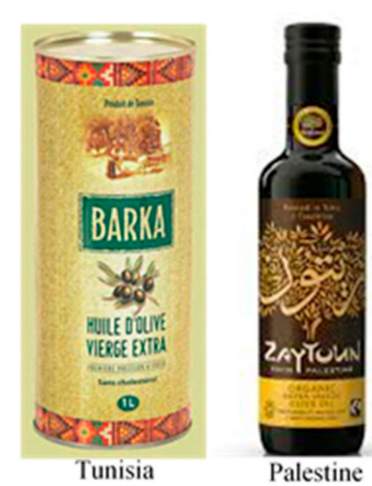

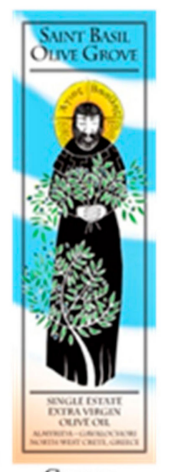

Greece

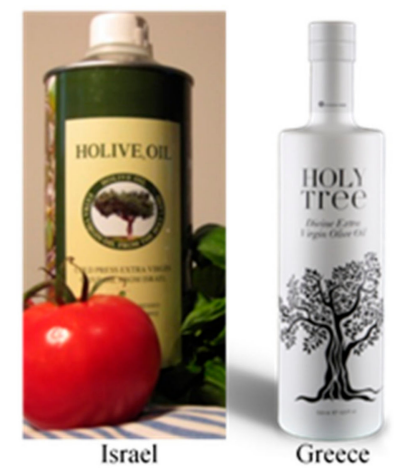

Greece

Figure 1. Olive oil products with religious images on labels and their countries of origin.

The question arises whether the religious, cultural images are valid to differentiate the Mediterranean olive oil, even in markets where consumers do not share the Mediterranean religions or 
its traditional cultures. The main objective of this study is made of two folds. The first is to evaluate the effect of religious and cultural information on olive oil on consumer behavior empirically. The second is to evaluate the efficacy of the impact of religious and cultural information outside the origin of the product with or without additional explanation about cultural and religious aspects of olives in the Mediterranean. These objectives are examined through the estimation of Japanese consumer's willingness to pay (WTP) for the Mediterranean olive oil labeled with the cultural, religious attribute in two groups; one is with the additional information, and the other is the controlled.

This study will provide a perspective for religious and cultural information of olive oil as a new strategy in the market, which has not been focused on before. It will lead to the re-evaluation of religions and cultures in general as new values. Promotion of the local economy of traditional societies and low-impact agriculture relating to the traditional perspectives we focus on will contribute to realizing our essential goal of a sustainable society. At the same time, our study will contribute to enhancing the preservation of traditional cultures that have been highly exposed to global society.

\section{Literature Review}

In conjunction with increasing awareness of sustainability due to food risks and environmental crises, many works of literature found the ethical/altruistic consumer behavior, overcoming individual interests and acting for the benefit of broader entities such as others, communities, and the environment [18-20]. In order to rediscover the new value of religions and cultures that form the basis of our dietary lives, we tried to position the issue from the research results on public good attributes. Within a couple of decades, several studies have been working to demonstrate and disprove the correlation between public good attributes and consumer behavior. Several approaches were taken by the studies of whether targeted public good attributes of food products influence consumer's WTP. Previous literature examined WTP following appeals to social responsibility such as supporting local farmers [21-23], minimizing risks from pesticides or antibiotic-resistant bacteria [24-26], and reducing harm to wildlife [27-29] and domesticated animals [30-32]. This wide range of researchers on various sustainable programs shows that the altruistic behavior of consumers, such as social welfare and social responsibility, is prevailing and becomes one of the significant factors of purchase. Tully et al. reviewed the researches according to the beneficiaries of humans, animals, and the environment and noted that there are more WTPs in programs that benefit humans than the environment [33].

Since all food is related to humans, the public good attributes of food are intensively discussed. It is also because food is a product that is consumed on a daily basis and has more opportunities for consumers to choose, compared to eco-fur or furniture made from sustainably sourced materials, which are only purchased several times a year. Previous studies examined whether labeling foods with area of origin or country of origin attracted consumers for US meats [34], German/Danish fish [29], or Italian wine [35]. Country or area of origin claims are often treated in the same context as domestic or local product claims. However, whether the good came from the same area or not could lead to different consumer behavior. Panzone et al. pointed out that when dividing respondents into insiders and outsiders and presenting a geographical indication of the same area as insiders, the insiders tend to prefer the product over the outsider group [8]. Loureiro et al. [36] attributed consumers' preference for domestic products to the recognition of their higher quality, while Lusk et al. [37] attributed it to protectionist or ethnocentric tendencies. Gilmore [38] and Menapace et al. [4] examined the effect of labeling country of origin or geographical indication on consumers' WTP outside a domestic context. Mtimet et al. [39] confirmed that labeling country of origin of foreign olive oil affects Japanese customers' WTP for the products from Spain and Italy. These studies suggest that with the information of country of origin and geographical indication, the geographical origin of other regions can add value to products beyond their territory. It supports our intuitive, the potential of information on religious and cultural traditions to be added-value to olive oil products in foreign markets. From the anthropological point of view based on Western discourses, Meneley claimed that the imageries 
of Mediterranean culture are formed in the North Atlantic society as a source of health benefits and sociability, and those imageries promote the use of olive oil [5].

Multiple cues such as cultures, histories, stories, and landscapes are embedded on labels of area of origin because it has symbolic and emotional meaning to consumers with sensory, affective, and ritual connotations [3,40]. Cultures that consist of values and norms of societies are the most effective factor in consumer behavior [16]. Furthermore, religion is one of the most universal and influential social institutions, which has a significant presence on people's attitudes at both the individual and societal levels [17]. The choice of product can be affected by the religious and cultural background of consumers as well as that of products.

The literature devoted extensive attention to religious influences on consumers in Muslim markets over the last decades [17,41-43]. Consumers' cultural affinities and religious inclinations can influence the choice of the product that suits their religion or culture. Even implicit norms that do not explicitly regulate our life, unlike doctrines, are also influencing consumer behavior. Grunert [44] found that tradition, atmosphere, social life, and status underlie consumers' motivation to buy beef in western European countries. While these cultural trends are unique to each society, Shavitt et al. [45], referring to the biaxial cultural theory of Triandis et al. [46], analyzed consumer behavior in each cultural region from brand strategies of their markets. According to his theory, the targeted society of our study has "vertical-collectivistic" propensity where hierarchical and normative values are emphasized, where a product made from one's own country is preferred particularly than those from foreign countries. However, the production of olive oil in Japan is extremely limited to about a couple dozen tons, and we did not include the option of Japan as a country of origin in the survey.

The possibilities of cultural connotations to add value to products in the market were also discussed in the literature. Tempesta et al. [47] noted that landscapes as cultural heritage elements on a wine label influence perceptions of quality. Bakar et al. [42] investigated how the Islamic symbol of a crescent on packaging influences product preferences and assessments among Pakistani consumers. Although these studies were conducted within the cultures as the same origin as the products, they demonstrated the possibility of the approach to step into the contents consisting of the image of area or country of origin. They give us the validity of the survey in the same orientation with different cultural settings. Apart from abounding studies of halal products [41,48-50], however, few studies addressed whether a product's cultural and religious connotations and symbols influence consumer choice, especially outside regional markets. In the following sections, we tried to fill this research gap by examining how religious and cultural information influences Japanese consumers' WTP for Mediterranean olive oil.

\section{Materials and Methods}

\subsection{Data Collection}

We surveyed Japanese consumers on the internet to explore whether the impact of religious, cultural attributes of olive oil on the consumer's WTP with the choice experiment (CE). We investigated how the attribute of "pilgrimage olive oil" affects consumer behavior in the Japanese market, which is far from the Mediterranean culture and has very little monotheistic influence [51]. Olive oil consumption in Japan has increased remarkably by 1387\% between 1990/91 and 2017/18 [1]. In recent years, although the production of olive oil in Japan has been small, the development of innovative products and agrotourism at olive farms on Shodoshima island has gained immense attention among Japanese. Therefore, the interest and demand for olive oil and olive cultivation among consumers is relatively high in Japan.

To investigate whether cultural and religious connotations influence olive oil consumers in Japan, we commissioned Intage Inc., a provider of online and offline research in Japan and Asia. We randomly selected 2478 women in their twenties to sixties in Tokyo and neighboring Saitama, Chiba, and Kanagawa Prefectures from the nearly 8,920,000 Intage monitors. The Basic Resident Registration 
System shows that $17.0 \%$ of residents are in their twenties, $20.3 \%$ their thirties, $25.0 \%$ their forties, $19.3 \%$ their fifties, and $18.4 \%$ their sixties, assuming the population from twenties to sixties in the four prefectures can be defined as $100 \%$ [52]. That is nearly the same age distribution as respondents of our survey: $16.3 \%$ twenties, $17.5 \%$ thirties, $25.7 \%$ forties, $20.3 \%$ fifties, and $20.2 \%$ sixties. According to the Japanese Ministry of Internal Affairs and Communications, $80.9 \%$ of Japanese aged six and older used the internet in 2017 [53]. Our web questionnaire, conducted February 21-26, 2018, received 526 valid responses with a response rate of $21.2 \%$.

Questions were asked in the form of a closed-ended question. The questionnaire had four parts. The first part asked about respondents' olive oil consumption and purchase frequencies, quantities consumed in a single answer style. The second part of the questionnaire asked about their familiarity with the cultural and religious connotations related to olives in a multiple answer style. In this part, we examined the associability of olive with certain countries, symbols, religions, and cultures. They were multiple-choice questions to grasp general images of olives among Japanese in cultural and religious contexts more extensively. The questions required respondents to choose associable countries with olive oil among Spain, Greece, Italy, Turkey, Morocco, Syria, Tunisia, Algeria, and others. They were also asked to choose associable terms with olives among Peace, Longevity, Good fortune, Health, Abundance, Fertility, Sacred tree, and others, as well as associable religions or cultures among Greek culture, Roman culture, Christianity, Islam, Amazigh, and others. Additionally, one pair of questions was provided in this part to measure respondents' knowledge of religious, cultural usages of olive oil; "Do you know that olive oil is used in rituals?" and "Do you know that olive oil is used as holy oil?" These questions employed a dichotomous-choice format, and respondents who chose Yes were asked to describe the source of her religious knowledge. To examine respondents' interest in the cultural and religious connotations of olives, we asked them to choose interesting olive oil products among three alternatives in three questions about sacred values, values of indigenous tradition, and longevity of olive trees. Each of them has specific characteristics, e.g., about sacredness, alternatives are "Made from a sacred olive tree," "Made from a tree of a sacred site," and "Made from a spirit-dwelling olive tree." If not interested, respondents chose "Not applicable." The choices for indigenity and longevity were provided in the same pattern. In selecting the options for the questions in the second part, we referred to the actual olive oil product labels as well as the results of field surveys obtained in Tunisia [15]. The third part was the CE, the core section of this study explained below. The last part was set to capture respondents' socio-demographic characteristics as gender, age, a place to live, marital state, number of children in a household, educational level, and annual income of a household with single-selection questions.

The respondents were asked whether they use olive oil at the very beginning of the questionnaire. The three available responses were (1) Yes, (2) No, but I may use it someday, and (3) No, and I do not think I ever will. To achieve results that approximate the impact on actual purchasing behavior, we limited respondents of the CE to those who currently use olive oil.

We designed and implemented the CE following the standard protocols [54,55], in which the respondents were given sets of alternative product descriptions and asked to select the one they would purchase. The product attributes and their levels were selected, referring to similar studies by Menapace et al. [4], Mtimet et al. [39], and Troiano et al. [35]. Cards in the CE presented four attributes: Country of origin, taste, religious connotation, and price of a $250 \mathrm{~mL}$ olive oil bottle. Country of origin labels included oils from the four main olive oil producer countries: Greece, Italy, Spain, and Tunisia. $250 \mathrm{~mL}$ is the minimum size of an olive oil bottle commonly sold in Japan. Based on this size, we set up the price range covering conventional oils to high premium oils. The religious connotation means whether the olive oil was produced in a pilgrimage destination. The attributes and their corresponding levels are in Table 1. 
Table 1. Selected olive oil attributes and their corresponding levels.

\begin{tabular}{cl}
\hline \multicolumn{1}{c}{ Attributes } & Levels \\
\hline \multirow{3}{*}{ Country of origin } & Spain \\
& Italy \\
& Tunisia \\
\hline \multirow{3}{*}{ Taste } & Sweet \\
& Bitter \\
& Pungent \\
\hline \multirow{2}{*}{ Religious connotation } & Produced in a pilgrimage destination \\
& Not produced in a pilgrimage destination \\
\hline \multirow{3}{*}{ Price (250 mL bottle) } & $400 \mathrm{JPY}$ \\
& 800 JPY \\
& $1200 \mathrm{JPY}$ \\
& $1600 \mathrm{JPY}$ \\
& $2000 \mathrm{JPY}$ \\
& $2400 \mathrm{JPY}$ \\
\hline
\end{tabular}

We asked respondents to choose among four alternatives: Three related to separate bottles of olive oil and a fourth alternative of no choice (do not buy). Each bottle had varying degrees of the four attributes. Table 2 illustrates a sample CE set.

Table 2. Choice experiment question and a sample card. "Which $250 \mathrm{~mL}$ olive oil bottle would you like to buy? Please check with $(\mathrm{X})$ below the selected alternatives".

\begin{tabular}{cccc}
\hline Bottle A & Bottle B & Bottle C & None \\
\hline Spain & Italy & Tunisia & \\
Sweet & Bitter & Pungent & I will not purchase \\
Produced in a pilgrimage & Not produced in a & Not produced in a & any bottle \\
destination & pilgrimage destination & pilgrimage destination & \\
$400 \mathrm{JPY}$ & $1200 \mathrm{JPY}$ & $2400 \mathrm{JPY}$ & \\
\hline
\end{tabular}

We divided respondents into two groups. Group 1 was informed about attributes and labels, particularly those indicating cultural and religious expression of olives in Tunisia and the Mediterranean. Group 2 was not informed. Information of items A to $C$ was given to Group 1, as shown in Table 3. To measure the relation between the respondents' interests on the religious, cultural information of olives and the results of the $\mathrm{CE}$, we asked the informed respondents to reveal the most interesting items of information among three with a ranking question.

Table 3. Cultural and religious information of olives.

\begin{tabular}{cl}
\hline Items & Explanation \\
\hline A & $\begin{array}{l}\text { Olives have been cultivated throughout the Mediterranean since antiquity. Their frequent } \\
\text { appearance in ancient myths shows their importance. }\end{array}$ \\
\hline B & $\begin{array}{l}\text { In Tunisia, on the southern shore of the Mediterranean, olives have supported life due to } \\
\text { their drought resistance. They have been used in traditional foods and medicines. }\end{array}$ \\
\hline C & $\begin{array}{l}\text { In Tunisia, olive trees are considered blessed, and some old olive trees are venerated. } \\
\text { Olive oil is said to have the power to bring happiness. }\end{array}$ \\
\hline
\end{tabular}

\subsection{Models}

As developed by Lancaster [56,57], a choice experiment (CE) is based on the assumption that products are bundles of attributes among which consumers select alternatives to maximize individual utility. Following Louviere et al. [54] and Hensher et al. [55], random utility theory holds that overall 
utility $\left(U_{i}\right)$ of consumer $i$ cannot be observed, but it can be expressed as the sum of a deterministic (observable) component $\left(V_{i}\right)$ and an unobservable random error $\left(\varepsilon_{i}\right)$. Thus, consumer $i$ 's utility for alternative $j$ is expressed as $U_{i j}=V_{i j}+\varepsilon_{i j}$. Consumer $i$ chooses alternative $j$ over alternative $k$ if $U_{i j}>U_{i k}$. The probability that consumer $i$ chooses alternative $k$ is:

$$
P_{i j}=\operatorname{Prob}\left(U_{i j}>U_{i k}\right)=\operatorname{Prob}\left(V_{i j}+\varepsilon_{i j}>V_{i k}+\varepsilon_{i k}\right), j \neq k, j \in C_{i}
$$

where $C_{i}$ is the choice set for consumer $i . \varepsilon_{i}$ is assumed to be identically and independently distributed within a type I extreme values distribution [58]. This condition leads the conditional logit model. Equation (1) indicates consumers choose an alternative from a number of choices to maximize their utility.

The conditional probability of alternative $j$ for consumer $i$ in choice set $C_{i}$ is expressed as:

$$
P_{i j}=\frac{\exp ^{V_{i j}}}{\sum_{k=1}^{k} \exp ^{V_{i k}}}, j \neq k .
$$

We consider the linear additive form of utility function $V_{i j}$ for the main effects model:

$$
V_{i}=\beta_{j}+\sum_{h=1}^{H} \beta_{h j} x_{h i j}
$$

where $x_{h i j}$ is the value of the $h$-th attribute of alternative $j$ for consumer $i . \beta_{h j}$ represents coefficients to be estimated, and $\alpha_{j}$ represents the intercept of alternative $j$. Our choice set is constant and includes four alternatives.

We employed a conditional logit model on the following linear random utility function. Considering the acceptable result of the goodness of fit measure, we adopt the conditional logit estimation.

$$
\begin{aligned}
V_{i}=\sum_{j} \beta_{A S C_{j}} \text { ASC }_{j}+ & \sum_{j} \beta_{C T} \text { Country }_{j}+\sum_{j} \beta_{\text {TS } \text { Taste }_{j}}+\sum_{j} \beta_{P G} \text { Pilgrim }_{j} \\
& +\sum_{j} \beta_{P G} \text { Pilgrim }_{j}+e_{i}
\end{aligned}
$$

where $V_{j}$ denotes random utility from the $i$ th respondent's choice, and $\mathrm{e}_{i}$ is the error term with a Gumbel distribution. The alternative specific constant $\left(A S C_{i}\right)$ takes 1 if the respondent chooses type $j$ olive oil, and 0 if otherwise. The attributes Country ${ }_{j}$, Taste $e_{j}$, Pilgrim ${ }_{j}$, and Price $e_{j}$ constitute deterministic utility. Country $y_{j}$ is a dummy variable for olive oil $j$, which denotes country of origin. Taste $e_{j}$ is a dummy variable of flavors of olive oil $j$. The variable Pilgrim $_{i}$ takes 1 if olive oil $j$ is from a pilgrimage destination, and 0 if otherwise. Price $j$ variations are 400, 800, 1200, 1600, 2000, and 2400 yen (JPY) per $250 \mathrm{~mL}$ bottle of olive oil. $\beta_{A S C j}, \beta_{C T i}, \beta_{T S i}, \beta_{T G i}$, and $\beta_{P G i}$ are parameters to be estimated.

Equation (4) can derive WTP as the marginal rate of substitution between an attribute and price for each product. Following Train [59], the marginal WTP of attribute $j$ can be given as the negative value of the ratio of parameters between attribute $j$ and price $\left(\beta_{P R j}\right)$ :

$$
M W T P_{j n}=-\frac{\beta_{n}}{\beta_{P R j}}
$$

where $n$ equals $C T, T S$, and $P G$, which represents attributes country of origin, taste, and product from a pilgrimage destination, respectively.

\section{Empirical Results and Discussion}

The questionnaire sought demographic information about respondents' age, marital status, income, education, and number of children per household. As Table 4 shows, respondents' average age is 45.7 years, nearly two-thirds are married, and there are 0.6 children per home. Median 
household income is 5 million yen to 6 million yen yearly. More than $36.3 \%$ of respondents graduated from universities.

Table 4. Characteristics of respondents.

\begin{tabular}{|c|c|c|c|}
\hline $\begin{array}{l}\text { Demographic } \\
\text { Characteristic }\end{array}$ & Subcategories & Percentages $(\%)$ & Age/Person \\
\hline Gender & Female & 100 & - \\
\hline \multirow[t]{2}{*}{ Age in years } & Mean & - & 45.7 (years old) \\
\hline & Min./max. & - & 20/69 (years old) \\
\hline \multirow[t]{2}{*}{ Civil status } & Married & 63.3 & - \\
\hline & Not married & 36.7 & - \\
\hline \multirow[t]{7}{*}{ Completed education level } & Junior high school & 1.3 & - \\
\hline & Senior high school & 25.3 & - \\
\hline & Junior college & 20.0 & - \\
\hline & University & 34.4 & - \\
\hline & Master/Doctoral course & 1.9 & - \\
\hline & Professional/tech. school & 16.2 & - \\
\hline & Others & 1.0 & - \\
\hline \multirow[t]{7}{*}{$\begin{array}{l}\text { Number of children in } \\
\text { household }\end{array}$} & Mean & - & 0.6 (person) \\
\hline & Min./max. & - & 0/4 (person) \\
\hline & 0 & 61.4 & - \\
\hline & 1 & 22.2 & - \\
\hline & 2 & 13.7 & - \\
\hline & 3 & 2.1 & - \\
\hline & 4 and over & 0.6 & - \\
\hline \multirow{14}{*}{$\begin{array}{l}\text { Household income } \\
\text { (million yen/year) }\end{array}$} & income $\leq 1$ & 2.7 & - \\
\hline & $1<$ income $\leq 2$ & 6.8 & - \\
\hline & $2<$ income $\leq 3$ & 12.5 & - \\
\hline & $3<$ income $\leq 4$ & 14.8 & - \\
\hline & $4<$ income $\leq 5$ & 9.3 & - \\
\hline & $5<$ income $\leq 6$ & 11.6 & - \\
\hline & $6<$ income $\leq 7$ & 10.1 & - \\
\hline & $7<$ income $\leq 8$ & 6.8 & - \\
\hline & $8<$ income $\leq 9$ & 4.0 & - \\
\hline & $9<$ income $\leq 10$ & 7.2 & - \\
\hline & $10<$ income $\leq 12$ & 7.4 & - \\
\hline & $12<$ income $\leq 15$ & 4.2 & - \\
\hline & $15<$ income $\leq 20$ & 2.3 & - \\
\hline & $20<$ income & 0.2 & - \\
\hline
\end{tabular}

Note: We valued " 4 and over" as 4 to calculate the mean and maximum of the number of children in household.

For the question about the usage of olive oil, 413 respondents selected "Yes," so they were categorized as current users. Fifty selected "No, but I may use it someday" as potential users, and 63 selected "No, and I do not think I ever will" as non-users. Only the responses of the current users were used for the analysis of the CE. Table 5 summarizes results of the CE. We estimated multinomial logit models for the informed, uninformed, and all respondents of 413. Models corresponded respectively to Group 1, Group 2, and Total.

According to the total results of the main effect model, olive oil made in Tunisia and Spain have negative significance compared to olive oil made in Italy. That indicates higher consumer preferences for Italian olive oil, followed by Tunisian and Spanish. The coefficient for attribute indicates no such trait for Group 2, but it is significant for Group 1. It means the religious, cultural information of olives influences the respondents' preference for Italian oil. The result of the control group was inconsistent with the findings of Mtimet et al. [39] that labeling country of origin of foreign products affected 
Japanese consumers' WTP for olive oil. In contrast, the significant preference of the factor of foreign country of origin was confirmed positively when the respondents were provided with the additional information on the cultures and religions of the countries of origin.

Negative coefficients for bitter and pungent tastes indicate that the respondents prefer a sweet taste. The negative coefficient for a pungent taste is statistically more significant than for a bitter. Group 1 does not have a negatively significant level of a bitter taste, but Group 2 and Total have. Possibly, the information mitigates the respondents' avoidance of bitterness.

The coefficient for the pilgrimage attribute is positive and significant for Group 1 and Total, indicating the consumers' preference of olive oil made in a pilgrimage destination to that of not. Comparing the results of Group 1 and 2, the cultural and religious information has a definite impact on the consumers' choice of a pilgrimage olive oil. Although there is no significance on the label of the pilgrimage attribute in the controlled group, the results of the informed group indicate significant preference on the attribute, following the investigation of Tempesta et al. [47] and Bakar at al. [42] that religious, cultural profiles can add value to products.

Table 5. Estimation results of the multinomial logit model for the two groups and the total.

\begin{tabular}{|c|c|c|c|c|c|c|}
\hline \multicolumn{7}{|c|}{ Group 1} \\
\hline & \multirow{2}{*}{$\begin{array}{c}\text { Main Effect } \\
\text { Model }\end{array}$} & \multicolumn{5}{|c|}{ Cross Effect Model } \\
\hline & & Main Effect & Education & Age & Child & Income \\
\hline Tunisia & $\begin{array}{c}-0.222 * * \\
{[0.092]}\end{array}$ & $\begin{array}{l}-0.022 \\
{[0.488]}\end{array}$ & $\begin{array}{l}-0.019 \\
{[0.078]}\end{array}$ & $\begin{array}{l}-0.004 \\
{[0.007]}\end{array}$ & $\begin{array}{l}-0.024 \\
{[0.123]}\end{array}$ & $\begin{array}{c}0.011 \\
{[0.020]}\end{array}$ \\
\hline Spain & $\begin{array}{c}-0.294^{* * *} \\
{[0.094]}\end{array}$ & $\begin{array}{c}0.240 \\
{[0.494]}\end{array}$ & $\begin{array}{l}-0.026 \\
{[0.079]}\end{array}$ & $\begin{array}{l}-0.007 \\
{[0.007]}\end{array}$ & $\begin{array}{l}-0.101 \\
{[0.126]}\end{array}$ & $\begin{array}{c}0.007 \\
{[0.021]}\end{array}$ \\
\hline Pungent & $\begin{array}{c}-0.592^{* * *} \\
{[0.089]}\end{array}$ & $\begin{array}{c}-1.049^{* *} \\
{[0.442]}\end{array}$ & $\begin{array}{c}0.072 \\
{[0.070]}\end{array}$ & $\begin{array}{c}0.007 \\
{[0.006]}\end{array}$ & $\begin{array}{l}-0.161 \\
{[0.112]}\end{array}$ & $\begin{array}{c}0.014 \\
{[0.018]}\end{array}$ \\
\hline Bitter & $\begin{array}{l}-0.043 \\
{[0.100]}\end{array}$ & $\begin{array}{c}0.093 \\
{[0.513]}\end{array}$ & $\begin{array}{l}-0.065 \\
{[0.083]}\end{array}$ & $\begin{array}{l}-0.001 \\
{[0.007]}\end{array}$ & $\begin{array}{c}0.049 \\
{[0.130]}\end{array}$ & $\begin{array}{c}0.009 \\
{[0.022]}\end{array}$ \\
\hline Pilgrim & $\begin{array}{c}0.194 * * \\
{[0.081]}\end{array}$ & $\begin{array}{c}0.621 \\
{[0.412]}\end{array}$ & $\begin{array}{c}-0.0001 \\
{[0.066]}\end{array}$ & $\begin{array}{c}-0.009 * \\
{[0.006]}\end{array}$ & $\begin{array}{l}-0.088 \\
{[0.103]}\end{array}$ & $\begin{array}{c}0.018 \\
{[0.017]}\end{array}$ \\
\hline Price & $\begin{array}{c}-0.0002^{* * * *} \\
{[0.00005]}\end{array}$ & $\begin{array}{c}-0.0002^{* * *} \\
{[0.00005]}\end{array}$ & & & & \\
\hline $\begin{array}{l}\text { Sample } \\
\text { respondents }\end{array}$ & 4872 & 4872 & & & & \\
\hline $\begin{array}{c}\text { Pseudo } R^{2} \\
\text { Log-likelihood }\end{array}$ & $\begin{array}{c}0.0376 \\
-2307.30\end{array}$ & $\begin{array}{c}0.0412 \\
-2298.62\end{array}$ & & & & \\
\hline \multicolumn{7}{|c|}{ Group 2} \\
\hline & \multirow{2}{*}{$\begin{array}{l}\text { Main Effect } \\
\text { Model }\end{array}$} & \multicolumn{5}{|c|}{ Cross Effect Model } \\
\hline & & Main Effect & Education & Age & Child & Income \\
\hline Tunisia & $\begin{array}{l}-0.047 \\
{[0.092]}\end{array}$ & $\begin{array}{l}-0.214 \\
{[0.460]}\end{array}$ & $\begin{array}{c}0.068 \\
{[0.074]}\end{array}$ & $\begin{array}{l}-0.003 \\
{[0.007]}\end{array}$ & $\begin{array}{l}0.203 * \\
{[0.114]}\end{array}$ & $\begin{array}{l}-0.038 \\
{[0.027]}\end{array}$ \\
\hline Spain & $\begin{array}{l}-0.145 \\
{[0.094]}\end{array}$ & $\begin{array}{c}-1.183^{* *} \\
{[0.475]}\end{array}$ & $\begin{array}{l}0.182 * * \\
{[0.076]}\end{array}$ & $\begin{array}{c}0.002 \\
{[0.007]}\end{array}$ & $\begin{array}{l}0.190 * \\
{[0.115]}\end{array}$ & $\begin{array}{l}-0.004 \\
{[0.027]}\end{array}$ \\
\hline Pungent & $\begin{array}{c}-0.658^{* * *} \\
{[0.088]}\end{array}$ & $\begin{array}{c}-0.901 \text { ** } \\
{[0.418]}\end{array}$ & $\begin{array}{c}0.045 \\
{[0.067]}\end{array}$ & $\begin{array}{c}0.004 \\
{[0.006]}\end{array}$ & $\begin{array}{c}-0.201 * \\
{[0.104]}\end{array}$ & $\begin{array}{c}0.032 \\
{[0.024]}\end{array}$ \\
\hline Bitter & $\begin{array}{c}-0.197^{*} \\
{[0.101]}\end{array}$ & $\begin{array}{l}-0.062 \\
{[0.503]}\end{array}$ & $\begin{array}{c}0.025 \\
{[0.081]}\end{array}$ & $\begin{array}{l}-0.001 \\
{[0.007]}\end{array}$ & $\begin{array}{l}-0.172 \\
{[0.125]}\end{array}$ & $\begin{array}{c}0.013 \\
{[0.029]}\end{array}$ \\
\hline Pilgrim & $\begin{array}{c}0.031 \\
{[0.081]}\end{array}$ & $\begin{array}{l}-0.309 \\
{[0.395]}\end{array}$ & $\begin{array}{c}0.227^{* * *} \\
{[0.064]}\end{array}$ & $\begin{array}{l}-0.009 \\
{[0.006]}\end{array}$ & $\begin{array}{c}-0.192 * * \\
{[0.097]}\end{array}$ & $\begin{array}{c}0.035 \\
{[0.023]}\end{array}$ \\
\hline Price & $\begin{array}{c}-0.0002^{* * *} \\
{[0.00005]}\end{array}$ & $\begin{array}{c}-0.0002^{* * *} \\
{[0.00005]}\end{array}$ & & & & \\
\hline $\begin{array}{c}\text { Sample } \\
\text { respondents }\end{array}$ & 4944 & 4944 & & & & \\
\hline Pseudo $\mathrm{R}^{2}$ & 0.0368 & 0.0471 & & & & \\
\hline Log-likelihood & -2343.37 & -2318.34 & & & & \\
\hline
\end{tabular}


Table 5. Cont.

\begin{tabular}{|c|c|c|c|c|c|c|}
\hline \multicolumn{7}{|c|}{ Total } \\
\hline & \multirow{2}{*}{$\begin{array}{c}\text { Main Effects } \\
\text { Model }\end{array}$} & \multicolumn{5}{|c|}{ Cross-Effects Model } \\
\hline & & Main Effect & Education & Age & Child & Income \\
\hline \multirow[t]{2}{*}{ Tunisia } & $-0.135 * *$ & -0.158 & 0.019 & -0.003 & 0.090 & -0.009 \\
\hline & [0.065] & {$[0.332]$} & {$[0.053]$} & {$[0.005]$} & {$[0.083]$} & {$[0.016]$} \\
\hline \multirow[t]{2}{*}{ Spain } & $-0.219^{* * *}$ & -0.511 & 0.075 & -0.001 & 0.053 & -0.002 \\
\hline & [0.066] & [0.338] & {$[0.054]$} & [0.005] & {$[0.083]$} & {$[0.016]$} \\
\hline \multirow[t]{2}{*}{ Pungent } & $-0.624^{* * *}$ & $-0.953^{* * *}$ & 0.056 & 0.005 & $-0.171 * *$ & 0.021 \\
\hline & [0.063] & [0.301] & {$[0.048]$} & {$[0.004]$} & {$[0.075]$} & {$[0.014]$} \\
\hline \multirow[t]{2}{*}{ Bitter } & $-0.119^{*}$ & -0.032 & -0.011 & -0.001 & -0.060 & 0.012 \\
\hline & {$[0.071]$} & {$[0.356]$} & [0.057] & [0.005] & [0.089] & [0.017] \\
\hline \multirow[t]{2}{*}{ Pilgrim } & $0.113^{* *}$ & 0.125 & $0.121^{* * *}$ & $-0.008^{* *}$ & -0.154 ** & 0.023 * \\
\hline & [0.057] & [0.282] & [0.045] & [0.004] & {$[0.070]$} & {$[0.013]$} \\
\hline \multirow[t]{2}{*}{ Price } & -0.0002 & $-0002 * * *$ & & & & \\
\hline & {$[0.00004]^{* * *}$} & {$[0.00004]$} & & & & \\
\hline \multirow{3}{*}{$\begin{array}{l}\text { Sample } \\
\text { respondents } \\
\text { Pseudo R }{ }^{2} \\
\text { Log-likelihood }\end{array}$} & 9816 & 9816 & & & & \\
\hline & 0.0366 & 0.0409 & & & & \\
\hline & -4653.43 & -4632.76 & & & & \\
\hline
\end{tabular}

To assess how the responders' socio-demographic characteristics influenced their choice of the attributes, we estimated cross-effects for their education, age, number of children, and income (Table 5). The selections of country of origin and taste have some significance. Better-educated respondents in Group 2 prefer Spanish olive oil. If they have more children, they mildly prefer Spanish and Tunisian olive oil to Italian. The respondents with more children in Group 2 tend to avoid a pungent taste. These tendencies are neutralized by the information.

Results for Group 2 and Total indicate that better-educated respondents value the pilgrimage attribute more highly. Unlike the main effects model, results are not significant for Group 1 and are highly significant for Group 2. We observed that the information has a negative impact on the highly educated respondents to choose the pilgrimage attribute. The older respondents in Total show less concern for the pilgrimage attribute of olive oil. Although the respondents with more children have the same tendency, the information can mitigate it for Group 1.

In the Japanese market, the combination of pilgrimage and olive oil is unique. Consumers who are interested in such novel products could be a younger or middle-aged generation who follows trends, the highly educated who are capable of the other culture, or the high-income class who seeks high value-added products. Buckley et al. [60] indicate that social elements of food are important for the adventurous food consumer, who is more likely to be middle-aged and highly educated, and in full-time employment. The conservative consumers are characterized as to be older, living in smaller households, and less likely to have children. This is inconsistent with our results, indicating that the consumer with more children shows a conservative tendency to avoid unconventional products as well as the older consumers.

To understand the relative values among the three groups, we estimated WTP for each attribute of olive oil in Table 6. Results show the respondents will pay a premium between 141 yen and 946 yen for pilgrimage olive oil. The premium for Group 1 is 6.7 times larger than for Group 2, indicating the strength of the religious, cultural information on the respondents' choice of the attribute of pilgrimage. The coefficient for price in the Total model is negative, but its low value indicates price marginally affects respondents' selection of olive oil. This finding parallels that in Mtimet et al. [39], where price parameters were -0.0015892 to -0.0019257 . 
Table 6. Consumers' willingness to pay (WTP) for each attribute.

\begin{tabular}{cccc}
\hline & Total & Group 1 & Group 2 \\
\hline \multirow{2}{*}{ Tunisia } & Coefficient & Coefficient & Coefficient \\
& $-640.336^{*}$ & $-1085.868^{*}$ & -216.014 \\
Spain & {$[343.762]$} & {$[564.011]$} & {$[432.014]$} \\
& $-1037.433^{* * *}$ & $-1436.393^{* *}$ & -660.953 \\
Pungent & {$[392.195]$} & {$[638.028]$} & {$[487.81]$} \\
& $-2948.295^{* * *}$ & $-2892.421^{* * *}$ & $-3005.411^{* * *}$ \\
Bitter & {$[673.489]$} & {$[976.881]$} & {$[929.221]$} \\
& -562.114 & -208.182 & -901.156 \\
Pilgrimage & {$[371.797]$} & {$[506.542]$} & {$[550.863]$} \\
& $533.312^{* *}$ & $946.99^{* *}$ & 141.426 \\
& {$[255.575]$} & {$[387.776]$} & {$[360.489]$}
\end{tabular}

Note: ***, and ${ }^{* * *}$ indicate significant at $10 \%, 5 \%$, and $1 \%$, respectively. The coefficient corresponding to "Made in Italy" is fixed at 0 as a base. The coefficient corresponding to "Sweet" is fixed at 0 as a base. The coefficient corresponding to "Not produced in a pilgrimage destination" is fixed at 0 as a base.

In the second part of the questionnaire, we examined the associability of religions or cultures for a grasp of general images of olives among Japanese in a multiple-choice question by asking, "Which of these religions/cultures do you associate with olives?" The results showed $54.8 \%$ of all respondents (n 526) chose Greek, and 43.7\% chose Roman culture as associable with olives. Thus, the religious and cultural impressions of olives are more associated with Greco-Roman than Christian (16.5\%), Islamic $(2.5 \%)$, or Amazigh $(0.4 \%)$ cultures. It may explain the respondents' general preference for Italian olive oil.

To measure the respondents' interest in cultural and religious characteristics of olive oil products, we asked them to choose interesting profiles of olive oil among three alternatives in three questions. The sets of items of each question concerned sacredness, and indigenity, and longevity of olive trees, respectively. If not interested, the respondents selected "Not applicable." We found that only $34.7 \%$, $26.4 \%$, and $41.0 \%$ of the respondents, respectively to each question, were interested in the alternatives, and more than half of the respondents were not interested in any of these product characteristics. The features of longevity of olive trees were the most interested, and indigenous characteristics of olive oil were the worst to gain the concern. The degree of concern differs according to each feature, from $7.9 \%$ as for olive oil "Made from an olive tree for rites of indigenous culture in North Africa" to $22.2 \%$ as for olive oil "Made from a thousand-year-old olive tree." The tendency of overall low degree of the concern is perhaps because only limited information about religious and cultural aspects of olives has been provided to Japanese consumers in general. This intuition is followed by the result that the characteristics of indigenity of olive oil that seems totally new to Japanese consumers got less attention than sacredness or longevity.

Our findings that religious, cultural information of olive has an impact on consumers' preference of olive oil follow the claim of Meneley [5] about the circulation of the imageries of the Mediterranean and the spread of olive oil. We investigated which kind of content in the imageries was more effective to the choice than others. To measure the effect of each item of the provided cultural, religious information on the respondents' choices, the informed respondents were asked to rank the A, B, and C parts of information according to their interest. Results showed that $22.8 \%$ of the respondents named item A (Greco-Roman myth) the most interesting informational tidbit, $45.5 \%$ found item B (Tunisian dietary-medicinal information) the most interesting, and 31.7\% named item $C$ (indigenous religion in Tunisia). We divided Group 1 into Sub-groups A, B, and C according to their preference for the items of information and estimated them by multinomial logit and cross-effects as in Table 7.

Sub-group A responded strongly to the pilgrimage attribute. It indicates that the informational item A strongly affectes the selection of the religious, cultural attribute, while the informational items B and $C$ did not. As stated previously, Japanese associated olives with Greek and Roman cultures more 
easily, probably because the knowledge of Greek and Roman mythologies seemed prevalent more than the others. Since the information of Greco-Roman mythologies seems less virtual than that of Tunisia for Japanese, the product image of pilgrimage olive oil is more associable with Greco-Roman cultures.

The other results of the second part also show this deviation. One pair of questions was provided to measure respondents' knowledge of religious, cultural usages of olive oil. To the first question "Do you know that olive oil is used in rituals?" 34.4\% of Sub-group A answered "Yes" compared with 11.5\% in B and 10.6\% in C. To the second question "Do you know that olive oil is used as holy oil?" $39.3 \%$ of Sub-group A answered "Yes" compared with $12.3 \%$ in B and $12.9 \%$ in C. Those results indicate the ratio of the people with religious and cultural knowledge on olive oil in Sub-group A is higher than that of Sub-groups B and C. It means the group who is interested in Greco-Roman cultures tends to have more knowledge about religious background of olive than the others.

Table 7. Estimation results of multinomial logit model according to the information preference among Sub-group A who choose item A (7-a), Sub-group B who choose info B (7-b), and Sub-group C who choose item $C(7-c)$ as the most interesting.

\begin{tabular}{|c|c|c|c|c|c|c|}
\hline \multicolumn{7}{|c|}{ 7-a. Results of Sub-Group A Who Choose Item A as the Most Interesting. } \\
\hline & \multirow{2}{*}{$\begin{array}{c}\text { Main Effect } \\
\text { Model }\end{array}$} & \multicolumn{5}{|c|}{ Cross-Effects Model } \\
\hline & & Main Effect & Education & Age & Child & Income \\
\hline \multirow[t]{2}{*}{ Tunisia } & -0.233 & -0.343 & 0.192 & -0.014 & -0.147 & 0.039 \\
\hline & [0.173] & [1.023] & [0.151] & [0.016] & [0.247] & [0.052] \\
\hline \multirow[t]{2}{*}{ Spain } & -0.102 & -1.296 & $0.331 * *$ & -0.014 & 0.189 & 0.035 \\
\hline & [0.173] & [1.003] & [0.148] & [0.015] & [0.226] & [0.050] \\
\hline \multirow[t]{2}{*}{ Pungent } & $-0.576^{* * *}$ & -0.316 & 0.076 & -0.019 & -0.130 & 0.078 * \\
\hline & [0.166] & [0.892] & [0.131] & [0.014] & [0.213] & [0.046] \\
\hline \multirow[t]{2}{*}{ Bitter } & -0.120 & -0.094 & -0.016 & -0.004 & -0.129 & 0.064 \\
\hline & [0.189] & [1.085] & [0.162] & [0.016] & [0.258] & [0.057] \\
\hline \multirow[t]{2}{*}{ Pilgrim } & $0.429^{* * *}$ & $-1.816^{* *}$ & $0.317^{* *}$ & 0.001 & 0.009 & $0.136^{* * *}$ \\
\hline & [0.149] & [0.876] & [0.129] & [0.013] & [0.196] & [0.044] \\
\hline \multirow[t]{2}{*}{ Price } & 0.0001 & 0.0001 & & & & \\
\hline & [0.0001] & [0.0001] & & & & \\
\hline \multirow{3}{*}{$\begin{array}{l}\text { Sample } \\
\text { respondents } \\
\text { Pseudo } \mathrm{R}^{2} \\
\text { Log-likelihood }\end{array}$} & 1272 & 1272 & & & & \\
\hline & 0.0246 & 0.0632 & & & & \\
\hline & -610.53524 & -586.39665 & & & & \\
\hline \multicolumn{7}{|c|}{ 7-b. Results of Sub-Group B Who Choose Info B as the Most Interesting. } \\
\hline & \multirow{2}{*}{$\begin{array}{l}\text { Main Effect } \\
\text { Model }\end{array}$} & \multicolumn{5}{|c|}{ Cross Effect Model } \\
\hline & & Main Effect & Education & Age & Child & Income \\
\hline \multirow[t]{2}{*}{ Tunisia } & 0.171 & -0.306 & 0.139 & 0.003 & 0.267 & -0.087 * \\
\hline & [0.141] & {$[0.696]$} & [0.116] & {$[0.010]$} & [0.171] & {$[0.050]$} \\
\hline \multirow[t]{2}{*}{ Spain } & -0.018 & $-1.499 * *$ & 0.207 * & 0.008 & $0.305^{*}$ & -0.023 \\
\hline & [0.145] & [0.737] & [0.122] & {$[0.011]$} & [0.172] & [0.048] \\
\hline \multirow[t]{2}{*}{ Pungent } & -0.760 & -0.863 & 0.014 & 0.011 & -0.194 & -0.030 \\
\hline & [0.136] & [0.642] & [0.106] & [0.009] & [0.157] & [0.045] \\
\hline \multirow[t]{2}{*}{ Bitter } & -0.276 & -0.662 & 0.055 & 0.012 & -0.172 & -0.019 \\
\hline & [0.152] & {$[0.771]$} & [0.127] & [0.011] & [0.184] & {$[0.050]$} \\
\hline \multirow[t]{2}{*}{ Pilgrim } & -0.142 & 0.961 & 0.087 & $-0.024^{* * *}$ & -0.184 & 0.004 \\
\hline & [0.123] & [0.590] & [0.102] & [0.009] & [0.138] & [0.039] \\
\hline \multirow[t]{2}{*}{ Price } & -0.0004 & $-0.0004^{* * *}$ & & & & \\
\hline & [0.0001] & {$[0.00008]$} & & & & \\
\hline $\begin{array}{c}\text { Sample } \\
\text { respondents }\end{array}$ & 2328 & 2328 & & & & \\
\hline Pseudo $R^{2}$ & 0.0628 & 0.0749 & & & & \\
\hline Log-likelihood & -1073.6017 & -1059.779 & & & & \\
\hline
\end{tabular}


Table 7. Cont.

\begin{tabular}{|c|c|c|c|c|c|c|}
\hline \multicolumn{7}{|c|}{ 7-c. Results of Sub-Group C Who Choose Item C as the Most Interesting. } \\
\hline & \multirow{2}{*}{$\begin{array}{l}\text { Main Effect } \\
\text { Model }\end{array}$} & \multicolumn{5}{|c|}{ Cross Effect Model } \\
\hline & & Main Effect & Education & Age & Child & Income \\
\hline \multirow[t]{2}{*}{ Tunisia } & -0.176 & -0.231 & -0.026 & -0.007 & 0.317 & -0.002 \\
\hline & [0.175] & [0.866] & [0.145] & [0.012] & [0.229] & [0.049] \\
\hline \multirow[t]{2}{*}{ Spain } & -0.356 & -0.548 & 0.051 & 0.003 & -0.049 & -0.003 \\
\hline & [0.181] & [0.896] & [0.146] & [0.013] & [0.268] & [0.048] \\
\hline \multirow[t]{2}{*}{ Pungent } & -0.628 & $-1.348^{*}$ & 0.103 & 0.006 & -0.294 & 0.079 * \\
\hline & [0.167] & [0.788] & [0.130] & [0.011] & [0.214] & [0.042] \\
\hline \multirow[t]{2}{*}{ Bitter } & -0.147 & 0.613 & 0.103 & -0.017 & -0.206 & -0.003 \\
\hline & [0.200] & [0.960] & [0.163] & [0.014] & {$[0.278]$} & [0.055] \\
\hline \multirow[t]{2}{*}{ Pilgrim } & -0.095 & 0.193 & $0.282 * *$ & -0.007 & $-0.488^{* *}$ & -0.037 \\
\hline & [0.158] & [0.769] & [0.126] & [0.011] & [0.230] & [0.043] \\
\hline \multirow[t]{2}{*}{ Price } & -0.0002 & $-0.0002^{* *}$ & & & & \\
\hline & [0.0001] & [0.0001] & & & & \\
\hline \multirow{3}{*}{$\begin{array}{l}\text { Sample } \\
\text { respondents } \\
\text { Pseudo R2 } \\
\text { Log-likelihood }\end{array}$} & 1344 & 1344 & & & & \\
\hline & 0.0426 & 0.0645 & & & & \\
\hline & -633.1733 & -618.72984 & & & & \\
\hline
\end{tabular}

According to the results of the cross-effects model, Sub-groups A and C have a positive significance on education and the choice of the pilgrimage attribute. Sub-groups $\mathrm{A}$ and $\mathrm{C}$ have a greater interest in religion and culture because the informational items $\mathrm{A}$ and $\mathrm{C}$ contain myth and tree veneration. Better-educated respondents who concern such information responded favorably to the pilgrimage olive oil. Sub-group B did not. Respondents interested in the cultivation, dietary, or medicinal associations of olive oil are not fascinated by the pilgrimage attribute even if they are highly educated.

\section{Conclusions}

This research was achieved under the question of whether the religious and cultural information had an impact on WTP of Japanese consumers. The results of the CE have shown that there is a positive impact of olive oil's religious and cultural attribute on Japanese consumers' preference regarding a premium of 141 yen to 946 yen. If the additional information is provided, the premium increases 6.7 times that of non-informed respondents, indicating a strong effect of the religious, cultural explanation on respondents' choice of the attribute of pilgrimage.

Concerning cross-effects, higher education generally relates to tolerance and understanding of cultural and religious associations. That is not the case for the older respondents and those with more children. Empirical results establish the respondents' preference for Italian over Tunisian and Spanish olive oil, perhaps because they are familiar with Italia as the country of origin of olive oil. It also corresponds to the result that Greco-Roman cultures occupy the general impression of olives among Japanese.

Among results for Sub-groups A, B, and C, Sub-group A tends to choose "pilgrimage olive oil." It is supported by the result that respondents with the knowledge of the religious and cultural aspects of olives could be found more in Sub-group A than B or C.

These empirical results strengthen our hypothesis that the rich cultural and religious background unique to the Mediterranean region makes it possible to differentiate the Mediterranean olive oil. Olive oil producers can market the religious and cultural connotations surrounding olives to differentiate their products in a global market. Greco-Roman images are promising to promote olive oil among 
Japanese consumers. Since the religious and cultural connotations of Mediterranean olive oil are largely Greco-Roman, to utilize unfamiliar regional images such as Tunisia requires the diffusion and the permeation of their religious, cultural backgrounds by more active promotion. However, they have potential attractiveness since the results of the above question on favorable information among A, B, and $\mathrm{C}$ indicates that $77.2 \%$ of respondents deemed the information about Tunisia the most interesting. We anticipate that consumers' evaluation of North African olive oil would increase if they are provided and learn more about the product's suitable "story" through promotion and labeling.

While a certain level of interest toward new information is expected, the results of the questions about the preference of the product profiles in regard to sacredness, indigenous tradition, and longevity show the significantly low level of the interest to strange information such as indigenous Amazigh culture. Although we presumed the relationship between the unfamiliarity of information and level of interest to information in the course of our research, we could not focus on this issue in this survey. It remains as one of our challenges for future work to find out the factors of new information that consumers prefer or not. Forming an attractive package for a targeted country from a set of background information will require marketing that is more tailored to the cultural characteristics of that country. Religious and cultural information that adds value to Mediterranean olive oil may vary depending on the country and culture to which the consumer belongs. This survey focused on the Japanese market, but a broader validation of its effectiveness will require further consumer surveys in new olive oil markets such as North America or Oceania.

Author Contributions: Funding acquisition, H.I. and T.K.; conceptualization of the idea, H.I., K.K., and T.K.; supervision, H.I. and K.K.; methodology and model, K.K.; statistic estimation, T.K. and K.K.; original writing and draft preparation, T.K., K.K.; review and editing, K.K. All authors have read and agreed to the published version of the manuscript.

Funding: The author acknowledges that this research is partially supported by the JST-JICA Science and Technology Research Partnership for Sustainable Development Project, Grant Number JPMJSA1506: Valorization of Bio-resources in Semi-Arid and Arid Land for Development, and by JSPS Grant-in-Aid for Young Scientists (B), Grant Number JP15K16623: Study on the Religious Significance of Plants in the Multilayered Cultural System of North Africa.

Acknowledgments: We would like to thank Kiyokazu Ujiie and Yuki Maruyama of University of Tsukuba for their technical support and constructive suggestions.

Conflicts of Interest: The authors declare no conflicts of interest.

\section{References}

1. International Olive Council, World Olive Oil Figure. Available online: http://www.internationaloliveoil.org/ estaticos/view/131-world-olive-oil-figures (accessed on 11 December 2019).

2. Gonzalez-Lamas, R. Can china become a major olive oil producer? Olive Oil Times, 16 July 2018. Available online: https://www.oliveoiltimes.com/olive-oil-business/can-china-become-a-major-olive-oil-producer/ 63700 (accessed on 11 December 2019).

3. Dekhili, S.; Sirieix, L.; Cohen, E. How consumers choose olive oil: The importance of origin cues. Food Qual. Prefer. 2011, 22, 757-762. [CrossRef]

4. Menapace, L.; Colson, G.; Grebitus, C.; Facendola, M. Consumers' preferences for geographical origin labels: Evidence from the Canadian olive oil market. Eur. Rev. Agric. Econ. 2011, 38, 193-212. [CrossRef]

5. Meneley, A. The olive and imageries of the Mediterranean. Hist. Anthropol. 2019. [CrossRef]

6. Fournier, L.S.; Michel, K. Mediterranean foods as cultural property? Towards an Anthropology of geographical indications. In Taste, Power, Tradition: Geographical Indication as Cultural Property, Göttingen Studies in Cultural Property; May, S., Sidali, K.L., Spiller, A., Tschofen, B., Eds.; Universitätsverlag Göttingen: Göttingen, Germany, 2017; Volume 10, pp. 76-86.

7. Dekhili, S.; d'Hauteville, F. Effect of the region of origin on the perceived quality of olive oil: An experimental approach using a control group. Food. Qual. Prefer. 2009, 20, 525-532. [CrossRef] 
8. Panzone, L.; Di Vita, G.; Borla, S.; D'Amico, M. When consumers and products come from the same place: Preferences and WTP for geographical indication differ across regional identity groups. J. Int. Food Agribus. Mark. 2016, 28, 286-313. [CrossRef]

9. Tempesta, T.; Vecchiato, D. Analysis of the factors that influence olive oil demand in the Veneto region (Italy). Agriculture 2019, 9, 154. [CrossRef]

10. Burkert, W. Greek Religion; Raffan, J., Ed.; Harvard University Press: Cambridge, MA, USA, 1985; pp. $221-222$.

11. Håland, E.J. The ritual year of Athena: The agricultural cycle of the olive, girl's rites of passage, and official ideology. J. Relig. Hist. 2012, 3, 256-284. [CrossRef]

12. Wirgin, W. The menorah as symbol of Judaism. Isr. Explor. J. 1962, 12, 140-142.

13. Polymerou-Kamilakis, A. The culture of olive tree. In Olive Oil: Chemistry and Technology, 2nd ed.; Boskou, D., Ed.; Taylor \& Francis: Champaign, IL, USA, 2006; pp. 1-13.

14. Kambanis, P. Oil of gladness: Ritual use of oil in religious sources. In Ode to the Olive Tree; Hellenic Folklore Research Centre of the Academy of Athens, Ed.; General Secretariat for Olympic Utilization, Hellenic Ministry of Culture: Athens, Greece, 2006; pp. 126-153.

15. Kitagawa, T. Pilgrimage to old olive trees and saint veneration in North Africa. Int. J. Arts Humanit. 2017, 5, 264-293.

16. Chegini, F.; Molan, S.B.; Kashanifar, S.S. An examination of the impact of cultural values on brand preferences in Tehran's fashion market. J. Financ. Econ. 2016, 36, 189-200. [CrossRef]

17. Khraim, H. Measuring religiosity in consumer research from Islamic perspective. Int. J. Mark. Stud. 2010, 2, 166-179.

18. Vermeir, I.; Verbeke, W. Sustainable food consumption: Exploring the consumer "attitude-behavior intention" gap. J. Agric. Environ. Ethics 2006, 19, 169-194. [CrossRef]

19. Lusk, J.L.; Nilsson, T.; Foster, K. Public preferences and private choices: Effect of altruism and free riding on demand for environmentally certified pork. Environ. Resour. Econ. 2007, 36, 499-521. [CrossRef]

20. Maaya, L.; Meulders, M.; Surmont, N.; Vandebroek, M. Effect of environmental and altruistic attitudes on Willingness-to-Pay for organic and fair trade coffee in Flanders. Sustainability 2018, 10, 4496. [CrossRef]

21. Bond, C.A.; Thilmany, D.; Bond, J.K. Understanding consumer interest in product and process-based attributes for fresh produce. Agribusines 2008, 24, 231-252. [CrossRef]

22. Hu, W.; Batte, M.T.; Woods, T.; Ernst, S. Consumer preferences for local production and other value-added label claims for a processed food product. Eur. Rev. Agric. Econ. 2011, 39, 489-510. [CrossRef]

23. Cembalo, L.; Migliore, G.; Schifani, G. Consumers in postmodern society and alternative food networks: The organic food fairs case in Sicily. New Medit 2012, 11, 41-49.

24. Florax, R.J.G.M.; Travisi, C.M.; Nijkamp, P. A meta-analysis of the willingness to pay for reductions in pesticide risk exposure. Eur. Rev. Agric. Econ. 2005, 32, 441-467. [CrossRef]

25. Ortega, D.L.; Wang, H.H.; Wu, L.; Olynk, N.J. Modeling heterogeneity in consumer preferences for select food safety attributes in China. Food Policy 2011, 36, 318-324. [CrossRef]

26. Cembalo, L.; Caso, D.; Carfora, V.; Caracciolo, F.; Lombardi, A.; Cicia, G. The "Land of Fires" toxic waste scandal and its effect on consumer food choices. Int. J. Environ. Res. Public Health 2019, 16, 165. [CrossRef]

27. Baird, I.G.; Quastel, N. Dolphin-safe tuna from California to Thailand: Localisms in environmental certification of global commodity networks. Ann. Assoc. Am. Geogr. 2011, 101, 337-355. [CrossRef]

28. Zander, K.; Feucht, Y. Consumers' willingness to pay for sustainable seafood made in Europe. J. Int. Food Agribus. Mark. 2017, 30, 251-275. [CrossRef]

29. Risius, A.; Janssen, M.; Hamm, U. Consumer preferences for sustainable aquaculture products: Evidence from in-depth interviews, think aloud protocols and choice experiments. Appetite 2017, 113, 246-254. [CrossRef] [PubMed]

30. Lagerkvist, C.J.; Hess, S. A meta-analysis of consumer willingness to pay for farm animal welfare. Eur. Rev. Agric. Econ. 2010, 38, 55-57. [CrossRef]

31. Clark, B.; Stewart, G.B.; Panzone, L.A.; Kyriazakis, I.; Frewer, L.J. Citizens, consumers and farm animal welfare: A meta-analysis of willingness-to-pay studies. Food Policy 2017, 68, 112-127. [CrossRef]

32. Grunert, K.G.; Sponntag, W.I.; Glanz-Chanos, V.; Forum, S. Consumer interest in environmental impact, safety, health and animal welfare aspects of modern pig production: Results of a cross-national choice experiment. Meat Sci. 2018, 137, 123-129. [CrossRef] [PubMed] 
33. Tully, S.M.; Winer, R.S. The role of the beneficiary in willingness to pay for socially responsible products: A meta-analysis. J. Retail. 2014, 90, 255-274. [CrossRef]

34. Loureiro, M.L.; Umberger, W.J. Assessing consumer preferences for country-of-origin labeling. J. Agric. Appl. Econ. 2005, 37, 49-63. [CrossRef]

35. Troiano, S.; Marangon, F.; Tempesta, T.; Vecchiato, D. Organic vs. local claims: Substitutes or complements for wine consumers? A marketing analysis with a discrete choice experiment. New Medit 2016, 15, 14-21.

36. Loureiro, M.L.; Umberger, W.J. Estimating consumer willingness to pay for country-of-origin labeling. J. Agric. Resour. Econ. 2003, 28, 287-301.

37. Lusk, J.L.; Anderson, J.D. Effects of country-of-origin labeling on meat producers and consumers. J. Agric. Resour. Econ. 2004, 29, 185-205.

38. Gilmore, F. A country-Can it be repositioned? Spain—The success story of country branding. J. Brand Manag. 2002, 9, 281-293. [CrossRef]

39. Mtimet, N.; Ujiie, K.; Kashiwagi, K.; Zaibet, L.; Nagaki, M. The Effects of Information and Country of Origin on Japanese Olive Oil Consumer Selection. In Proceedings of the European Association of Agricultural Economists 2011 Congress, Zurich, Switzerland, 30 August-2 September 2011. Available online: https://core.ac.uk/download/pdf/6699221.pdf (accessed on 11 December 2019).

40. Verlegh, P.W.J.; Steenkamp, J.B.E.M. A review and meta-analysis of country-of-origin research. J. Econ. Psychol. 1999, 20, 521-546. [CrossRef]

41. Abdul, M.; Ismail, H.; Hashim, H.; Johari, J. Consumer decision making process in shopping for halal food in Malaysia. China USA Bus. Rev. 2009, 8, 40-47.

42. Bakar, A.; Lee, R.; Rungie, C. The effect of religious symbols in product packaging on Muslim consumer responses. Aust. Mark. J. 2013, 21, 198-204. [CrossRef]

43. Suki, N.M.; Suki, N.M. Does religion influence consumers' green food consumption? Some insights from Malaysia. J. Consum. Mark. 2015, 32, 551-563. [CrossRef]

44. Grunert, K.G. What's in a steak? A cross-cultural study on the quality perception of beef. Food Qual. Prefer. 1997, 8, 157-174. [CrossRef]

45. Shavitt, S.; Cho, H. Culture and consumer behavior: The role of horizontal and vertical cultural factors. Curr. Opin. Psychol. 2016, 8, 149-154. [CrossRef]

46. Triandis, H.C.; Gelfand, M.J. Converging measurement of horizontal and vertical individualism and collectivism. J. Personal. Soc. Psychol. 1998, 74, 118-128. [CrossRef]

47. Tempesta, T.; Giancristofaro, R.A.; Corain, L.; Salmaso, L.; Tomasi, D.; Boatto, V. The importance of landscape in wine quality perception: An integrated approach using choice-based conjoint analysis and combination-based permutation tests. Food Qual. Prefer. 2010, 21, 827-836. [CrossRef]

48. Tieman, M.; Ghazali, M.C.; van der Vorst, J.G.A.J. Consumer perception on halal meat logistics. Br. Food J. 2013, 115, 1112-1129. [CrossRef]

49. Zailani, S.; Kanapathy, K.; Iranmanesh, M.; Tieman, M. Drivers of halal orientation strategy among halal food firms. Br. Food J. 2015, 117, 2143-2160. [CrossRef]

50. Bashir, A.M.; Bayat, A.; Olutuase, S.O.; Latiff, Z.A.A. Factors affecting consumers' intention towards purchasing halal food in South Africa: A structural equation modelling. J. Food Prod. Mark. 2019, 25, $26-48$. [CrossRef]

51. Japanese Agency for Cultural Affairs. Shukyo Nenkan Reiwa 1; (Religious Yearbook, 2019), 35. Available online: https://www.bunka.go.jp/tokei_hakusho_shuppan/hakusho_nenjihokokusho/shukyo_nenkan/pdf/ r01nenkan.pdf (accessed on 8 January 2020).

52. E-Stat, 2017. Demographic Survey Result of Population Based on the Basic Resident Registration, Japanese Ministry of Internal Affairs and Communications. Available online: https://www.e-stat.go.jp/stat-search/files?page=1\&layout=datalist\&toukei $=00200241 \&$ tstat $=$ $000001039591 \&$ cycle=7\&year $=20170 \&$ tclass $1=000001039601 \&$ stat_infid $=000031598570 \&$ second $2=1$ (accessed on 11 December 2019).

53. Information and Communications Bureau, 2018. Information and Communications in Japan: White Paper, 2018. Ministry of Internal Affairs and Communications, 64. Available online: http://www.soumu.go.jp/ johotsusintokei/whitepaper/eng/WP2018/chapter-5.pdf (accessed on 11 December 2019).

54. Louviere, J.J.; Hensher, D.A.; Swait, J.D. Stated Choice Methods: Analysis and Applications; Cambridge University Press: Cambridge, UK, 2000. 
55. Hensher, D.A.; Rose, J.M.; Greene, W.H. Applied Choice Analysis, 2nd ed.; Cambridge University Press: Cambridge, UK, 2015.

56. Lancaster, K.J. A new approach to consumer theory. J. Political Econ. 1966, 74, 132-157. [CrossRef]

57. Lancaster, K.J. Consumer Demand: A New Approach; Columbia University Press: New York, NY, USA, 1971.

58. McFadden, D. Conditional logit analysis of qualitative choice behavior. In Frontiers in Econometrics; Zarembka, P., Ed.; Academic Press: New York, NY, USA, 1974; pp. 105-142.

59. Train, K.E. Discrete Choice Methods with Simulation, 2nd ed.; Cambridge University Press: New York, NY, USA, 2009.

60. Buckley, M.; Cowan, C.; McCarthy, M.; O'Sullivan, C. The convenience consumer and food-related lifestyles in Great Britain. J. Food Prod. Mark. 2005, 11, 3-25. [CrossRef]

(C) 2020 by the authors. Licensee MDPI, Basel, Switzerland. This article is an open access article distributed under the terms and conditions of the Creative Commons Attribution (CC BY) license (http://creativecommons.org/licenses/by/4.0/). 